\title{
Rhinoviruses: a Numbering System
}

\author{
Several laboratories have collaborated on a project to identify distinct \\ serotypes of rhinoviruses, and to organize them into a convenient \\ numbering system. They have prepared the following statement*.
}

RhINoviruses have emerged as the most important of the known aetiological agents of adult upper respiratory illnesses ${ }^{1-7}$. Taxonomically, they are classified as a subgroup of the picornaviruses because of certain biophysical and biochemical properties which include (1) small size (15-30 $\mathrm{m \mu}) ;(2)$ ribonucleic acid (RNA) core; (3) ether resistance; and (4) complete or almost complete inactivation at $p \mathrm{H} 3 \cdot 0$ (ref. 8 ). This last property distinguishes the rhinovirus from the enterovirus sub-group of picornaviruses.

Almost ninety rhinovirus serotypes have been described as potential new candidate viruses ${ }^{9}$. This large number of described rhinoviruses and the knowledge that many of them had not been tested by neutralization tests against all previously reported serotypes prompted the National Institute of Allergy and Infectious Diseases (NIAID) Veccine Development Branch (VDB) and the World Health Organization (WHO) to institute a collaborative rhinovirus programme to compare the antigenic relationships of rhinoviruses in order to arrive at an acceptable rhinovirus numbering system. It was considered essential to assemble the numerous rhinovirus serotypes into a suitable numbering scheme, because the rapidly increasing number of serotypes made interpretation of epidemiological data from various laboratories difficult and also prevented many laboratories from making epidemiologic investigations of rhinovirus infection. The Vaccine Development Branch, therefore, awarded a contract to the Children's Hospital Research Foundation, Children's Hospital, Columbus, Ohio, to act as a reference laboratory with the immediate task of performing reciprocal neutralization tests with the candidate rhinoviruses and sera submitted to the programme.

At a rhinovirus workshop held on January 25, 1965, and attended by active investigators in the field, each laboratory which was represented submitted a list of candidate rhinoviruses which had been tested against all available rhinovirus antisera and which appeared to be distinct serotypes. After this meeting a few additional rhinoviruses were added to the list by various laboratories; a total of sixty-eight viruses were included in this initial phase of the programme. Participants at this workshop agreed that the following requirements were to be fulfilled before a virus was submitted to the programme as a candidate prototype. These were (1) each candidate rhinovirus was to be "purified" either by three terminal dilution passages in tube cultures or by three single plaque passages; (2) data concerning the biophysical and biochemical properties of each candidate rhinovirus were to include evidence that the virus was ether resistant, acid labile, less than $50 \mathrm{~m} \mu$ in diameter and possessed an RNA core; (3) antigenic distinctness of the candidate rhinovirus was to be established by noutralization tests with all other known candidate antisera which were available at the time the virus was submitted; (4) evidence of human origin was to be demonstrated by a fourfold or greater rise in neutralizing antibody in paired sera from at least one person from whom the virus was obtained or recovery of the virus from two or more individuals.

* The signatories are: A. Z. Kapikian (Chairman), R. M. Conant, V. V Hamparian, R. M. Chanock, P. J. Chapple, E. C. Dick, J. D. Fenters, J. M. Gwaltney, jun., D. Hamre, J. C. Holper, W. S. Jordan, jun., E. H. Lennette, and D. A. J. Tyrrell.
Each laboratory was asked to submit to the Reference Laboratory $25 \mathrm{ml}$. (in $1 \mathrm{ml}$. portions) of each candidate virus and $100 \mathrm{ml}$. (in $2 \mathrm{ml}$. portions) of specific hyperimmune antiserum. In the Reference Laboratory each of the sixty-eight viruses was tested by the neutralization technique (using approximately $32-320$ T.C.D..$_{50}$ ) against each of the sixty-eight antisera (at dilutions of from $1: 2$ to $1: 20$ ) while each submitting laboratory tested its candidate virus or viruses against all available sera in a similar manner. In this way each candidate virus was tested independently against each specific antiserum in at least two laboratories. When a virus was neutralized by the screening dilution of serum, a reciprocal neutralization endpoint test was performed to determine the extent of that relationship. All the viruses included in the programme were "purified" by tube terminal dilution or plaque methods by the laboratory describing the virus except for the "coryzaviruses" $11,12,13,14,15,16,17$, 18 , 28 which were "purified" by the Laboratory of Infectious Diseases (LID), NIAID, NIH, Bethesda, Maryland, and "coryzaviruses" 19, 21, 22, 24, 25, 26, 27, 29 , 30 which were "purified" by the Common Cold Research Unit (C.C.R.U.), Salisbury, England, so that these "coryzaviruses" could be included in the pro. gramme. All sera were prepared by the laboratory describing the virus, or by Abbott Laboratories, Inc., under contract to the VDB, except for sera to "coryzaviruses" $11,12,13,14,15,16,17,18,28$ which were prepared by the LID, NIAID, NIH, and sera for "coryzavirus" (CV) 24 which was prepared by the C.C.R.U., and sera for "coryzaviruses" $19,21,22,25,26,27,29,30$ which were prepared by the California State Department of Public Health Laboratory (Dr. Lennette). All sera used in the programme were prepared from "purified" virus except for the aforementioned sera to "coryzaviruses" $19,21,22,25,26,27,29,30$ which were prepared as working reagents before the collaborative programme had begun and which were only available in small quantities but were used so that these "coryzaviruses" could be included in the programme. In addition, all neutralization tests for each virus were performed by the laboratory describing the virus with the exception of the "coryzaviruses" for which most of the laboratory tests were performed by the University of Chicago (Dr. Hamre), and Echo-28 for which most laboratories performed the required reciprocal neutralization tests because reagents for this virus were available to most laboratories before this collaborative programme was initiated.

In June 1966, when all the neutralization tests had been completed, a meeting on rhinovirus nomenclature was held, which was attended by all the collaborating laboratories with the exception of the Common Cold Research Unit of Salisbury, England. Data from the Salisbury laboratory were presented to the meeting.

At this meeting each laboratory presented the crossneutralization data on the viruses which they had submitted and these results were compared with those of the Reference Laboratory. There was complete agreement among the collaborators and the Reference Laboratory with regard to major cross-reactions. Various collaborating laboratories reported minor cross-reactions. In the Reference Laboratory, however, it was observed that treatment of the sera with human liver powder eliminated these minor cross-reactions in almost all instances. A 
complete description of the results of the neutralization tests carried out by the Reference Laboratory will be presented in a later communication from that laboratory ${ }^{10}$.

A candidate rhinovirus was considered to be distinct if at least twenty times the limiting concentration of specific antisera which neutralized $32-320$ T.C.D.50 of the other serotypes (that is, 20 antibody units) failed to neutralize 3-320 T.C.D. ${ }_{50}$ of the candidate virus and if at least 20 antibody units of serum to the candidate virus failed to neutralize $32-320$ T.C.D. ${ }_{50}$ of each of the other serotypes. Of the sixty-eight viruses submitted to the programme six pairs of viruses and three groups of three viruses were found to be identical by the aforementioned criteria; this reduced the number of candidate rhinoviruses by twelve. In addition the only viruses which were found to be significantly related, but not identical, were Echo-28 and B632. After roviewing all available data, it was agreed that $B 632$ be designated a sub-type of Echo-28. It was the unanimous agreement of the participants that the prototype strain among identical viruses should be that virus which was first described in a scientific publication or, if not yet described, then that

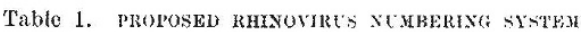

\begin{tabular}{|c|c|c|}
\hline $\begin{array}{l}\text { Rhinovirus } \\
\text { No. }\end{array}$ & Prototype strain* & $\begin{array}{l}\text { Refermees des ribing } \\
\text { indirated st rains }\end{array}$ \\
\hline $1 \mathrm{~A}$ & Echo-28 & 11,12 \\
\hline 1B & $B 832[K 779]$ & $13,[14]$ \\
\hline 2 & $H G P$ & 13 \\
\hline 3 & $F E B$ & 13 \\
\hline 4 & $16 / 60$ & 13 \\
\hline 5 & Norman & 13 \\
\hline 6 & Thompson & 13 \\
\hline 7 & $68-C V 11$ & 15 \\
\hline 8 & $M R H-C V 12$ & 15 \\
\hline 9 & $211-C V 13$ & 15 \\
\hline 10 & $204-C V 14$ & 15 \\
\hline 11. & $1-C V 1.5$ & 15 \\
\hline 12 & $181-C V 16$ & 15 \\
\hline 13 & $353[5,007-C V \geq 3]$ & $16,17,[18]$ \\
\hline 14 & 1,059 & 16,17 \\
\hline 15 & 1,734 & 16,17 \\
\hline 16 & 11,757 & 16,17 \\
\hline 17 & 33,342 & 16.17 \\
\hline 1.8 & $5,986-C, V 17$ & 18 \\
\hline 19 & $6,072-C V 18$ & 18 \\
\hline 20 & $15-C V 19$ & 18 \\
\hline 21 & $47-C V 21$ & 18 \\
\hline 22 & $127-C V^{2} 2\left[203 F^{\prime}\right]$ & $18,[19,6]$ \\
\hline 23 & $5,124-C V 24(100,319)^{*}$ & $18,(9)$ \\
\hline 24 & $5,146-C V 25[147 H]$ & $18,[19,6]$ \\
\hline 25 & $5,426-C V 26(K 2,218)^{*}(55,216)^{*}$ & $18,(20),(9)$ \\
\hline 26 & $5,660-C V 27(127-1)^{*}$ & $18,(19,6)$ \\
\hline 27 & $5,870-C V 28$ & 18 (x) \\
\hline 28 & $6,101-C V 23(113 E)^{*}$ & $18,(19,6)$ \\
\hline 29 & $5,582-C V 30(179 E)^{*}$ & $18,(21,6)$ \\
\hline 30 & $106 F$ & 21,6 \\
\hline 31 & $140 F^{\prime}$ & 21,6 \\
\hline 32 & 363 & 22 \\
\hline 33 & 1,200 & 22 \\
\hline 34 & $137-3$ & 19,6 \\
\hline 35 & $164 \mathrm{~A}$ & 19,6 \\
\hline 36 & 34211 & 19 ' \\
\hline 37 & $151-1$ & 19,6 \\
\hline 38 & $C H 79 \dagger\left[\begin{array}{ll}201 & 3 C\end{array}\right]$ & $1,7,\{19,6 !$ \\
\hline 39 & $209\lceil 00052]$ & $28,[6]$ \\
\hline 40 & $1,794[184 E]$ & $23,[19,6]$ \\
\hline 41 & $56,110\left[137 F^{1}\right]$ & $23,\lceil 19,6]$ \\
\hline 42 & $56,822[248 A]$ & $23,[6]$ \\
\hline 43 & $\begin{array}{l}58,750(E 2 \text { No. } 133)^{*}(\text { WIS } 258 E)^{*} \\
\text { [04374] }\end{array}$ & $23,(20),(24),[6]$ \\
\hline 44 & 71,560 & 23 \\
\hline 45 & Baylor $1(037211)^{*}(\text { L2 No. } 16)^{*}$ & $25,(6),(20)$ \\
\hline 46 & Baylor $2[477-C V$ 50] $[C H ? 02+]$ & $25 .\{26\},[1]$ \\
\hline 47 & $\begin{array}{l}\text { Baylor } 3[1,979 M-C V 46] \\
\text { [CII } 310+1\end{array}$ & $25,[26],[1]$ \\
\hline 48 & 1,505 & 9 \\
\hline 49 & 8.213 & 9 \\
\hline 50 & $A 2 \times 0.58$ & 20 \\
\hline 51 & $F_{0}(1-4,0 \Omega 1(19,143) *[605-C V 45]$ & $27,(9),[26],[19,6]$ \\
\hline 52 & $F 01-3,772(16,41.3) *[515-C V 34]$ & $27,(9),[26]$ \\
\hline 53 & $F 01-3,028[252 B]$ & $27,[6]$ \\
\hline 54 & $701-3,774\{2,253-C V 49\}$ & $27,[26]$ \\
\hline 55 & WIS 315E [Baylor 4] & $24,[28]$ \\
\hline
\end{tabular}

* Virus in parentheses represents a virus submitted to programme by a collaborating laboratory and found to be identical to the prototype strain virus in brackets represents a virus not included in first phase or not sub mitted to programme and found to be identical with the prototype strain by a collaborating laboratory. Reference numbers are shown in a similar manne to above. Thus, reference number not in parentheses refers to prototype
strain, number in parentheses refers to virus strain in parentheses. Number strain, number in parentheses refers to virus
in brackets refers to virus strain in brackets.

+ $C H 79$ was formerly designated as $C H V / 2 / 59 ; C H 202$ formerly designated as $\mathrm{CIIV/7/59}$; CII 310 formerly designated $C H V / 1 / 00$.

The number immediately following any CV ("coryzavirus") designation in this table represents a type number assigned to the indieated strain by the the term originally used to describe these strains $(15,18,26)$. virus which was first submitted to the Reference Laboratory.

It was also unanimously agreed that a rhinovirus numbering system should be based on a strict chronological system, that is, precedence in number should bo given to the virus which had been described earlier in the literature, or, if not yet described, precedence in number should be given according to the date the virus was submitted to the Reference Laboratory. According to these agreements a system of numbering rhinoviruses from 1 to 55 with one sub-type was unanimously adopted.

After this meeting, the data and numbering system were presented to the collaborators at the Common Cold Research Unit, Salisbury, England; they endorsed the system. The nomenclature system was also presented at the meeting of the Directors of the World Health Organization Respiratory and Enterovirus Reference Centres in Moscow, U.S.S.R., who unanimously approved it and suggested its publication as soon as possible. They also recommended that the numbering system be presented to the International Sub-committee on Virus Nomenclature for their information. The numbering system approved by the collaborating laboratories is shown in Table 1.

A second phase of the programme is now in progress, and additional viruses will be tested against the fiftyfive numbered rhinoviruses, to determine whether they represent now serotypes. Some viruses were received at the Reference Laboratory too late to be included in the first phase and others were excluded for other reasons. For example, one large group of viruses, the "coryzaviruses" 20 and 34-53, could not be included because neither terminally diluted virus nor adequate amounts of antiserum were available. $C H 82(C H V / 3 / 59)$ virus which was submitted to the first phase could not be included because untreated antiserum against this virus showed high level non-specific neutralization to many rhinoviruses ${ }^{1}$. The D.C. virus, first described in 1953, was not submitted to the first phase of the programme ${ }^{29}$. These and other candidate rhinoviruses will be investigated in the second phase of the collaborative programme.

Investigators who wish to submit rhinoviruses for investigation in the programme should contact either the Laboratory of Infectious Diseasos, NIAID, NIH, Bethesda, Maryland (Dr. A. Z. Kapikian), or the Common Cold Research Unit, Salisbury, England (Dr. D. A. J. Tyrrell)-both laboratories are designated as WHO Inteinational Reference Centros for Respiratory Diseases Other Than Influenza.

${ }^{1}$ (łwaltney, jun., J. M., and Jordan, jun., W. S., Bact. Rev., 28, 109 (1964).

${ }^{2}$ Chanock, R. M., Mufson, M. A., and Johnson, K. M., Prog. Med. Vir., 7, $208(1965)$.

${ }^{3}$ Phillips, C. A., Riggs, S., Melnick, J. L., and Grim, C. A., J. Amer. Med. Assoc, 192, $277(1965)$

4 Mufson, M. A., Webb, P. A., Kennedy, H., Gill, V., and Chanock, R. M., J. Amer. Med. Assoc., 195, I (1965).

5yrrell, D. A. J... in Common Colds and Reluted Diseases, 155 ('The Williams and Wilkins Co., Baltimore, and A rnolds, Jondon, 1965).

"Hamre, D., Connelly, jun., A. P., and Procknow, J. J., Amer. J. Fipid., 83. $283(1966)$.

${ }^{7}$ (iwaltney, J. M., and Jordan, jun., W. S., Amer. Rev. Resp. Dis., 43, 36" (1966)

B 'Tyrrell, D. A. J., and Chanock, R. M., Science, 141, 152 (1963).

" Kanikian A. Z, Mufson, M. A. James, jun. H. Kalica, A. R. Bloom. H. H., and Chanock, R. M., Proc. Soc. Exp. Biol. Med.122, 115. (1966).

${ }^{10}$ Hamparian, V. V., and Conant, R. M. (in preparation).

Pelon, W., Mogabgab, W. J., Phillips, I. A., and Pierce, W. F., Bact. Irok.. 67 (1956).

12 Price, W. H., Proc. U.S. Nat. Acad. Sci., 42, 892 (1956).

${ }_{13}$ Taylor-Robinson, D., and Tyrrell, D. A. J., Lancet, i, 452 (1962).

is Mogabgab, W. J., Amer, J. Hyif., 76, 160 (1982).

${ }^{15}$ Hamparian, V. V., Ketler, A., and Hilleman, M. R., Proc. Suc. Fxp. Biol. and Med., 108, 444 (1961).

${ }^{6}$ Johnson, K. M., Bloom, H. H., Chanock, R. M., Mufson, M. A., and Knight, V., Amer. I. Pub. Health, 52, 933 (1962).

${ }^{17}$ Johnson, K. M., and Rosen, I., Amer. J. Hyg., 77, 15 (1963).

${ }^{18}$ Ketler, A., Hamparian, V. V., and Hilleman, M. R.. Pror. Sir. Exp. Biol. and Med., 110, 821 (1962).

${ }^{19}$ Hamre, D., Connelly, jun., A. P., and Procknow, J. ... I. Lab. Clin. Med., 64, $450(1964)$.

(continued on next page) 